\title{
Quantification of mantle attachment scars on the Margaritifera margaritifera (Margaritiferidae, Bivalvia) shell
}

\author{
AA Zotin ${ }^{1}$, EP Ieshko ${ }^{2}$ \\ 1 Koltzov Institute of Developmental Biology of Russian Academy of Sciences (Moscow, Russian Federation) \\ 2 Institute of Biology of Karelian Research Centre, Russian Academy of Sciences (Petrozavodsk, Respublica Karelia, Russian Federation)
}

Corresponding author: AA Zotin (zotin@idbras.ru)

Academic editor: Yuliya V. Bespalaya • Received 24 May 2019 • Accepted 1 July 2019 • Published 16 July 2019

Citation: Zotin AA, Ieshko EP (2019) Quantification of mantle attachment scars on the Margaritifera margaritifera (Margaritiferidae, Bivalvia) shell. Arctic Environmental Research 19(2): 81-86. https://doi.org/10.3897/issn2541-8416.2019.19.1.81

\begin{abstract}
A characteristic feature shared by all Margaritiferidae mussels consists in the presence of scars on the internal surface of their shells. These scars mark places of mantle attachment by specific epithelial cells. According to some authors, such parameters of mantle attachment scars as the density and degree of their manifestation can be used for the purposes of species identification. To this end, quality indicators (numerous or few, pronounced or poorly visible scars) are typically used; however, the use of quantitative criteria is preferable. This work was aimed at developing quantitative indicators of mantle attachment scars in the Margaritifera margaritifera freshwater pearl mussels for the populations of the Syuskyuyanyoki and Livoyoki rivers (Karelia). It is shown that the density and size of mantle attachment scars are approximately the same for all the investigated shell samples. These parameters display the absence of dependence on the age and size of molluscs. The regression coefficients for the linear dependence of the density or size of mantle attachment scars on the age or length of the shell show no significant difference from 0 . For all the investigated molluscs, the density and size of mantle attachment scars are established to vary within the range of $0.37-1.16 \mathrm{scars} / \mathrm{cm}^{2}(0.71 \pm 0.03$ scars $/ \mathrm{cm}^{2}$ on average $)$ and $215-690 \mu \mathrm{m}(417 \pm 2 \mu \mathrm{m}$ on average), respectively. According to a two-factor analysis of variance, the distribution of mantle attachment scars appears to be irregular across the shell surface. At the same time, a significant $(p<0.001)$ increase in their density is observed in the posterior and ventral directions, as well as diagonally in the posterior ventral direction. Issues associated with the application of the investigated parameters for the purposes of mollusc species identification are discussed.
\end{abstract}

\section{Keywords}

bivalve mussels, density of mantle attachment scars, freshwater pearl mussels, Livoyoki river, Syuskyuyanyoki river

Copyright Zotin AA, leshko EP. This is an open access article distributed under the terms of the Creative Commons Attribution License (CC-BY 4.0), which permits unrestricted use, distribution, and reproduction in any medium, provided the original author and source are credited. 


\section{Introduction}

For the majority of bivalve molluscs, the mantle is attached to the shell by retractor muscles located along the mantle line (Zatsepin and Filatova 1968). However, a different type of attachment has been described for the Margaritiferidae and Trigoniida molluscs, which involves modified mantle epithelial cells and associated connective fibres (Smith 1983). The scars in the places of mantle attachment are round or oval in shape and can be used for determining the belongingness of molluscs to Margaritiferidae (Smith 2001; Huff et al. 2004; Graf and Cummings 2006; Bogan and Roe 2008; Araujo et al. 2009, 2016; Bolotov et al. 2015, 2016; Zotin 2017). In addition, the number and size of mantle attachment scars can be used for identifying various Margaritiferidae species. Frequently used qualitative characteristics (numerous or few, pronounced or poorly visible scars) lead to a subjective assessment of species (Smith 2001; Vikhrev et al. 2017; Zotin 2017). Therefore, the development of quantitative criteria is important for providing a more objective assessment of the species characteristics of mantle attachment scar parameters.

In this work, we aimed to conduct a quantitative analysis of mantle attachment scars on the shell surface of Margaritifera margaritifera L. 1785 by their density, size and distribution pattern.

\section{Materials and methods}

Samples of M. margaritifera (Margaritiferidae, Bivalvia) shells were collected across the riverbed and along the banks of the Syuskyuyanyoki (Lake Onega basin, Karelia) and Livoyoki (Kem river basin, Karelia) rivers. A total of 30 molluscs from the population of the Syuskyuyanyoki river and 13 molluscs from the population of the Livoyoki river were examined.

The images of the side of the shell pearlescent layer were obtained using an HPScanJet5400c scanner (China). A grid was applied on the obtained images dividing the shell into four parts along the length and into three parts along the width (Fig. 1A). Thus, the entire surface of the shell was divided into 12 cells. This number of cells is sufficiently small to contain the number of mantle attachment scars suitable for statistical processing
A

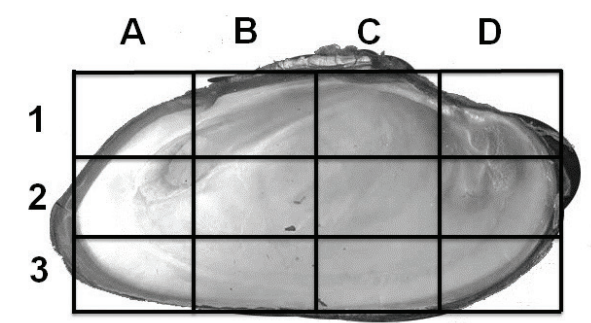

\section{B}

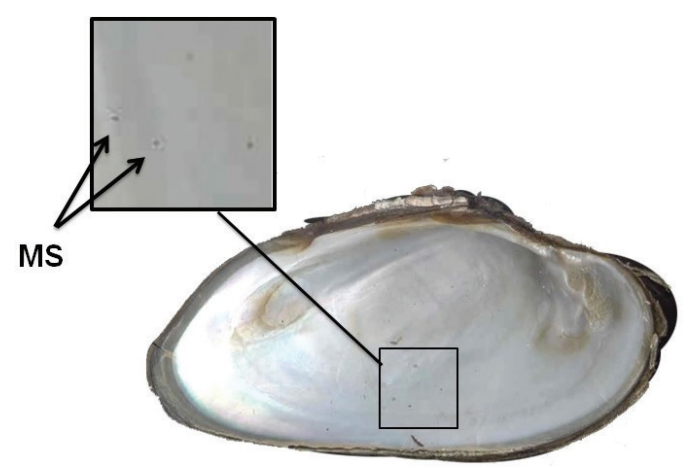

Fig. 1. A Division scheme of a shell surface into cells; A-D: posterior-anterior direction, 1-3: dorso-ventral direction. B Mantle attachment scars (MS) on the inner surface of a Margaritifera margaritifera shell

and is large enough to estimate the distribution of scars on the valve surface. The number of mantle attachment scars $n$ (Fig. 1B) was counted in each grid cell.

For each cell and the entire valve, the area $S$ of the projection of the pearl layer onto the plane was measured using the UniversalDesktopRuler 3.8 program (AVPSoft, Russia). The density of mantle attachment scars was calculated by the $n / S$ and $\Sigma n / \Sigma S$ formulas for each cell and the entire valve, respectively. The shell length and the maximum size of each mantle attachment scar were also measured using UniversalDesktopRuler 3.8 (AVPSoft, Russia).

The average values and standard errors of the mean for the density of mantle attachment scars and their size were calculated. When the number of data was lower than 50, the hypothesis of normal distribution of the data was evaluated using the Shapiro-Wilk test (Shapiro and Wilk 1965). Otherwise, the $\chi^{2}$ criterion (Plokhinsky 1970) was applied.

The distribution of the density of mantle attachment scars on the shell surface was evaluated using 
a two-factor ANOVA. In other cases, a one-factor ANOVA was used (Plokhinsky 1970).

The dependence of the density of mantle attachment scars on the age and length of the mollusc shell was estimated using linear regression analysis (Plokhinsky 1970).

\section{Results}

According to the criteria used for the distribution of all compared parameters, such as the density and size of mantle attachment scars for each cell and the entire valve, the average values for different molluscs have shown no difference from the normal distribution.

According to one-factor ANOVA, significant differences in the density of mantle attachment scars
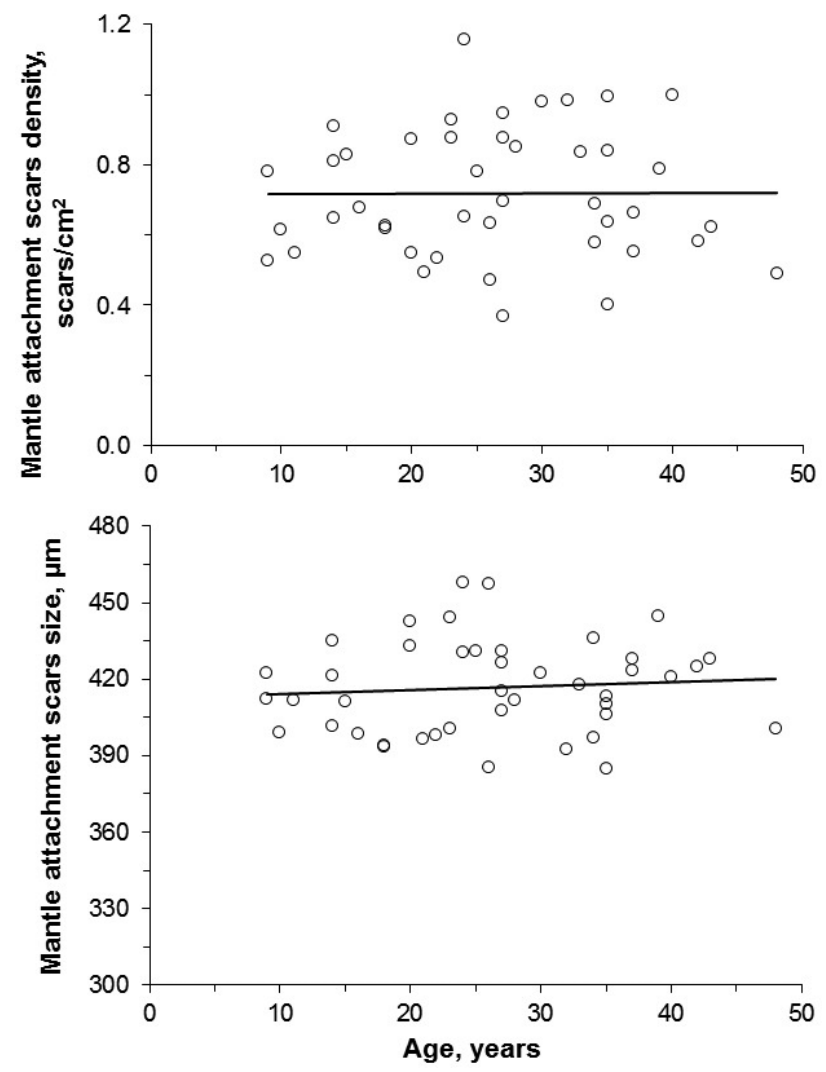

Fig. 2. Dependencies of the density of mantle attachment scars (top) and their sizes (bottom) on age. The circles denote experimental data. Lines are approximation by linear regression equations: for the upper plot $Y=0.0001 X+0.7167\left(R^{2}=\right.$ $\left.3 \times 10^{-5}\right)$; for the lower plot $Y=0.153 X+412.75\left(R^{2}=0.0069\right)$ and their sizes are not significant when comparing the following parameters: right and left valves, different individuals in each of the populations studied, molluscs from different populations.

No dependences of the density of mantle attachment scars and their maximum size on age were established (Fig. 2). The regression coefficients for the age dependence of the density and the size of mantle attachment scars are equal to $0.00010 \pm 0.00288 \mathrm{scars} /\left(\mathrm{cm}^{2}\right.$ year $)(n=43)$ and 0.153 $\pm 0.287 \mu \mathrm{m} /$ year $(n=43)$, respectively. In both cases, the difference in regression coefficients from 0 is insignificant.

For all the studied molluscs, the density of mantle attachment scars varies from 0.37 to $1.16 \mathrm{scars} / \mathrm{cm}^{2}$ and equals $0.71 \pm 0.03 \mathrm{scars} / \mathrm{cm}^{2}(n=43)$ on average. The maximum size of mantle attachment scars varies from 215 to $690 \mu \mathrm{m}$, with its average value being $417 \pm 2 \mu \mathrm{m}(n=1984)$.

The analysis of the distribution of mantle attachment scars on the shell surface has shown no significant difference in their density for the same cells in different shells regardless of whether the right or left valve of the same mussel, different individuals of the same population or mussels of different populations were compared. The average densities of mantle attachment scars are presented in Table 1.

Table 1. The average density of mantle attachment scars per $1 \mathrm{~cm}^{2}$ in different cells of the shell

\begin{tabular}{|c|c|c|c|c|c|}
\hline \multirow[t]{2}{*}{ Line } & \multicolumn{4}{|c|}{ Column } & \multirow[t]{2}{*}{ Entire valve } \\
\hline & A & B & $\mathbf{C}$ & D & \\
\hline \multicolumn{6}{|c|}{ Population of the Syskyuyanyoki river (30 samples) } \\
\hline \multicolumn{6}{|c|}{ Left valve } \\
\hline 1 & $0.49 \pm 0.14$ & $0.55 \pm 0.08$ & $0.52 \pm 0.06$ & $0.24 \pm 0.09$ & $0.66 \pm 0.05$ \\
\hline 2 & $0.78 \pm 0.13$ & $0.70 \pm 0.07$ & $0.49 \pm 0.07$ & $0.55 \pm 0.08$ & \\
\hline 3 & $1.00 \pm 0.20$ & $0.95 \pm 0.10$ & $0.62 \pm 0.08$ & $0.62 \pm 0.08$ & \\
\hline \multicolumn{6}{|c|}{ Right valve } \\
\hline 1 & $0.90 \pm 0.20$ & $0.63 \pm 0.10$ & $0.42 \pm 0.07$ & $0.67 \pm 0.24$ & $0.66 \pm 0.05$ \\
\hline 2 & $0.65 \pm 0.08$ & $0.68 \pm 0.08$ & $0.38 \pm 0.05$ & $0.64 \pm 0.10$ & \\
\hline 3 & $1.12 \pm 0.16$ & $0.81 \pm 0.08$ & $0.67 \pm 0.08$ & $1.03 \pm 0.17$ & \\
\hline \multicolumn{6}{|c|}{ Population of the Livoyoki river (13 samples) } \\
\hline \multicolumn{6}{|c|}{ Left valve } \\
\hline 1 & $1.28 \pm 0.48$ & $1.12 \pm 0.25$ & $0.76 \pm 0.17$ & $0.69 \pm 0.38$ & $0.87 \pm 0.10$ \\
\hline 2 & $0.96 \pm 0.09$ & $1.09 \pm 0.10$ & $0.63 \pm 0.09$ & $0.73 \pm 0.10$ & \\
\hline 3 & $0.75 \pm 0.14$ & $0.57 \pm 0.10$ & $0.96 \pm 0.10$ & $0.72 \pm 0.13$ & \\
\hline \multicolumn{6}{|c|}{ Right valve } \\
\hline 1 & $1.47 \pm 0.30$ & $1.13 \pm 0.21$ & $1.20 \pm 0.45$ & $1.17 \pm 0.47$ & $0.88 \pm 0.10$ \\
\hline 2 & $1.11 \pm 0.17$ & $1.26 \pm 0.17$ & $0.63 \pm 0.10$ & $0.44 \pm 0.06$ & \\
\hline 3 & $0.75 \pm 0.11$ & $0.64 \pm 0.05$ & $0.69 \pm 0.07$ & $0.57 \pm 0.09$ & \\
\hline
\end{tabular}

Notes: Location of the selected cells of the shell is presented in Fig. 1B. The average values and standard errors of the mean for the density of mantle attachment scars are provided. 
According to a two-factor ANOVA, the distribution of mantle attachment scars appears to be irregular across the shell surface. At the same time, a significant increase in their density is observed in the posterior direction $(20.2 \%, p<0.001)$, ventral direction $(7.4 \%, p<0.001)$ and diagonally in the posterior ventral direction $(5.5 \%, p<0.001)$ (Fig. 3).

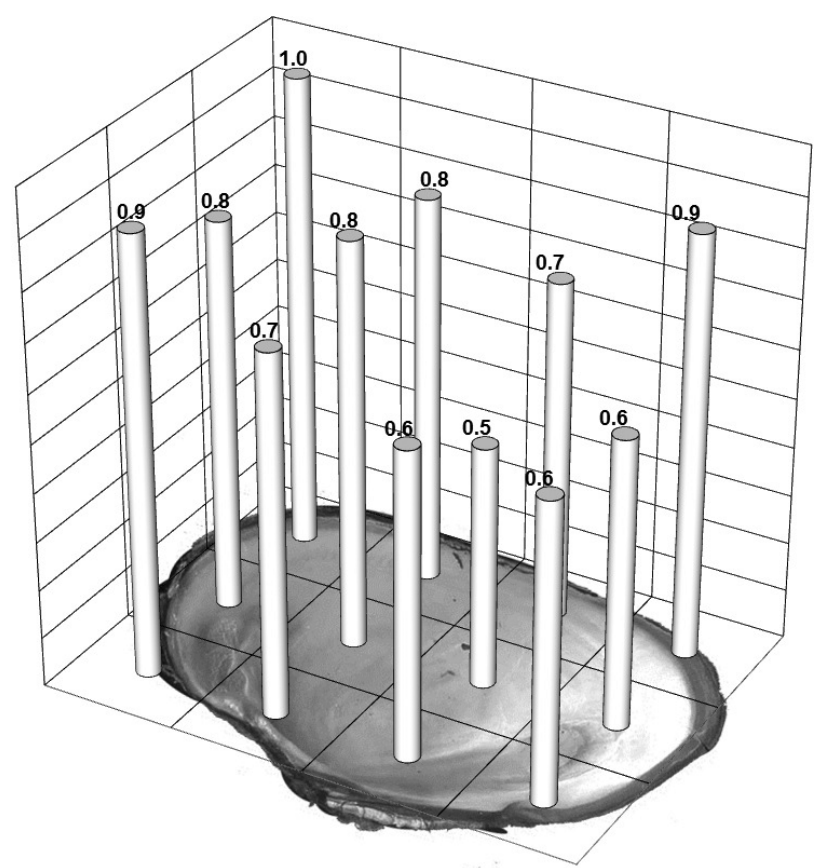

Fig. 3. The density distribution of the mantle attachment scars on the Margaritifera margaritifera valve. The numbers above the columns display average values for all the studied molluscs in this cell

\section{Discussion}

According to the obtained data, at least for two $M$. margaritifera populations, the density, surface distribution and size of mantle attachment scars are the same for different mussels both within the same population and for different populations. The density of mantle attachment scars tends to increase in the posterior and ventral directions, which agrees well with Smith's data obtained for various species of Margaritiferidae (Smith 2001).

We found only one publication on the density of mantle attachment scars, in which three species of Far Eastern pearl mussels - M. dahurica Middendorff
1850, M. laevis Haas 1910 and M. middendorffi Rozen 1926 - showed no significant difference in terms of this parameter (Bolotov et al. 2015). On this basis, the authors concluded that the density of mantle attachment scars was inapplicable as a diagnostic parameter of differentiation between species. Unfortunately, no specific values of the density of mantle attachment scars were provided. Therefore, we performed our own measurements using the shell images given in this paper. We carried out similar measurements using the photos for M. falcata Gould 1850 published in (Poppe and Poppe 2019).

As a result, we obtained the following values for the density of mantle attachment scars for $M$. dahurica, $M$. laevis and M. middendorffi: $0.30 \pm 0.08,0.36 \pm$ 0.04 and $0.26 \pm 0.01 \mathrm{scars} / \mathrm{cm}^{2}$, respectively. For each species, the measurements were carried out for four valves. The differences of these values for the three Far Eastern species are found to be insignificant, though they are significantly lower than those for $M$. margaritifera $\left(0.71 \pm 0.03 \mathrm{scars} / \mathrm{cm}^{2} ; p<0.001\right)$. At the same time, the density of mantle attachment scars for $M$. falcata $\left(0.87 \pm 0.12 \mathrm{scars} / \mathrm{cm}^{2}, 5\right.$ valves $)$ is similar to that for M. margaritifera (the differences are insignificant). Thus, it can be assumed that the density of mantle attachment scars can indeed serve as a diagnostic parameter, at least in distinguishing the European species M. margaritifera and the American species $M$. falcata from the Far Eastern ones.

Another indicator claiming to be the key in determining species consists in the size of mantle attachment scars. According to our calculations, the largest sizes of scars are observed for $M$. dahurica (687 \pm 15 $\mu \mathrm{m}, n=47$ ). For M. laevis, M. middendorffi and $M$. margaritifera, the size of mantle attachment scars is approximately the same, being equal to $445 \pm 9 \mu \mathrm{m}$ $(n=58), 433 \pm 31 \mu \mathrm{m}(n=14)$ and $417 \pm 2 \mu \mathrm{m}(n=$ 1984), respectively. For M. falcata, the size of mantle attachment scars is smaller and is estimated to be $202 \pm 22 \mu \mathrm{m}$ on average $(n=49)$. The smallest values of this parameter, which were calculated only for two scars on one shell by the image given in (Smith 2001), were observed for Gibbosula laosensis Lea 1863 (about $50 \mu \mathrm{m}$ ).

It goes without saying that the small number of conducted measurements imposes constraints on us- 
ing the density and size of mantle attachment scars as a parameter of species differentiation. Further studies are required to confirm this hypothesis.

\section{Conclusion}

No differences in the size and density of the mantle attachment scars on the inner surface of $M$. margaritifera shells were found either within the populations or between the populations inhabiting the Syuskyuyanyoki and Livoyoki rivers. Therefore, the studied quantitative parameters have shown a certain level of stability. A preliminary analysis of our own and literature data suggests that both the density of mantle attachment scars and their size can be applicable as key features in distinguishing species. According to the density of mantle attachment scars, Margaritifera

\section{References}

- Zatsepin YaYa, Filatova ZA (1968) Class Bivalves (Bivalvia). In: Zenkevich LA (Ed.) Animal life Vol. 2 - Invertebrates. Prosveschenie publishing house, Moscow, 95-155. [in Russian]

- Plokhinsky NA (1970) Biometrics. Publishing House of Moscow University, Moscow, 367 p. [in Russian]

- Araujo R, Toledo C, Van Damme D, Ghamizi M, Machordom A (2009) Margaritifera marocana (Pallary, 1918): a valid species inhabiting moroccan rivers. Journal of Molluscan Studies 75: 95-101. https://doi.org/10.1093/mollus/eyn043

- Araujo R, Schneider S, Roe KJ, Erpenbeck D, Machordom A (2016) The origin and phylogeny of Margaritiferidae (Bivalvia, Unionoida): a synthesis of molecular and fossil data. Zoologica Scripta 46: 289-307. https://doi.org/10.1111/zsc.12217

- Bogan AE, Roe KJ (2008) Freshwater bivalve (Unioniformes) diversity, systematics, and evolution: status and future directions. Journal of the North American Benthological Society 27(2): 349-369. https://doi.org/10.1899/07-069.1

- Bolotov IN, Bespalaya YuV, Vikhrev IV, Aksenova OV, Aspholm PE, Gofarov MYu, Klishko OK, Kolosova YuS, Kondakov AV, Lyubas AA, Paltser IS, Konopleva ES, Tumpeesuwan S, Bolotov NI, Voroshilova IS (2015) Taxonomy and distribution of freshwater pearl mussels (Unionoida: Margaritiferidae) of the Russian Far East. PLoS ONE 10(5): e0122408. https:// doi.org/10.1371/journal.pone.0122408 molluscs can be divided into two groups: $M$. dahurica, M. laevis, M. middendorffi (scar density is app. $0.3 / \mathrm{cm}^{2}$ ) and M. margaritifera, M. falcata (scar density is app. $0.7-0.8 / \mathrm{cm}^{2}$ ). In terms of the size of mantle attachment scars, the following four groups of species can be distinguished: $M$. dahurica (the size of mantle attachment scars is about $700 \mu \mathrm{m})$, M. laevis, M. middendorffi and $M$. margaritifera $(\sim 400 \mu \mathrm{m}), M$. falcata $(\sim 200 \mu \mathrm{m})$ and Gibbosula laosensis $(\sim 50 \mu \mathrm{m})$.

\section{Acknowledgments}

The study was conducted as part of the state program of basic scientific research of the Koltzov Institute of Developmental Biology, Russian Academy of Sciences, no. 0108-2019-0003. The study was carried out under state order (project № 0218-2019-0075).
- Bolotov IN, Vikhrev IV, Bespalaya YuV, Gofarov MYu, Kondakov AV, Konopleva ES, Bolotov NN, Lyubas AA (2016) Multi-locus fossil-calibrated phylogeny, biogeography and a subgeneric revision of the Margaritiferidae (Mollusca: Bivalvia: Unionoida). Molecular Phylogenetics and Evolution 103: 104-121. https://doi.org/10.1016/j.ympev.2016.07.020

- Graf DL, Cummings KS (2006) Palaeoheterodont diversity (Mollusca: Trigonioida + Unionoida): what we know and what we wish we knew about freshwater mussel evolution. Zoological Journal of the Linnean Society 148(3): 343-394. https:// doi.org/10.1111/j.1096-3642.2006.00259.x

- Huff SW, Campbell D, Gustafson DL, Lydeard C, Altaba CR, Giribet G (2004) Investigations into the phylogenetic relationships of the threatened freshwater pearlmussels (Bivalvia, Unionoidea, Margaritiferidae) based on molecular data: Implications for their taxonomy and biogeography. Journal of Molluscan Studies 70(4): 379-388. https://doi.org/10.1093/ mollus/70.4.379

- Poppe GT, Poppe P (2019) Conchiology. Shell Encyclopedia. https://www.conchology.be/?t=66\&family=MARGARITIFERIDAE

- Smith DG (1983) On the so-called mantle muscle scars on shells of the Margaritiferidae (Mollusca, Pelecypoda), with observations on mantle-shell attachment in the Unionoida 
and Trigonioida. Zoologica Scripta 12: 67-71. https://doi. org/10.1111/j.1463-6409.1983.tb00550.x

- Smith DG (2001) Systematics and distribution of the recent Margaritiferidae. In: Bauer G, Wächtler K (Eds) Ecology and Evolution of the Freshwater Mussels Unionoida. Ecological Studies (Analysis and Synthesis), Vol 145. Springer, Berlin, Heidelberg, 33-49. https://doi.org/10.1007/978-3-642-56869-5_3

- Vikhrev IV, Bolotov IN, Altun A, Gofarov MYu, Dvoryankin GA, Kondakov AV, Ozcan T, Ozcan G (2017) The revenant: rediscovery of Margaritifera homsensis from Orontes drainage with remarks on its taxonomic status and conservation (Bivalvia: Margaritiferidae). Systematics and Biodiversity 16(1): 69-80. https://doi.org/10.1080/14772000.2017.1343876

Zotin AA (2017) Definition of genera and species of the family Margaritiferidae (Bivalvia, Unionida). East European Science Journal 1: 4-10. 